Meta

Journal des tradlucteurs

Translators' Journal

\title{
Screening Potential Interpreters
}

\section{Barbara Moser-Mercer}

Volume 30, numéro 1, mars 1985

Interprétation de conférence

URI : https://id.erudit.org/iderudit/003631ar

DOI : https://doi.org/10.7202/003631ar

Aller au sommaire du numéro

Éditeur(s)

Les Presses de l'Université de Montréal

ISSN

0026-0452 (imprimé)

1492-1421 (numérique)

Découvrir la revue

Citer cet article

Moser-Mercer, B. (1985). Screening Potential Interpreters. Meta, 30(1), 97-100.

https://doi.org/10.7202/003631ar d'utilisation que vous pouvez consulter en ligne.

https://apropos.erudit.org/fr/usagers/politique-dutilisation/ 


\title{
SCREENING POTENTIAL INTERPRETERS
}

\author{
BARBARA MOSER-MERCER
}

\section{INTRODUCTION}

Based on a model for simultaneous interpretation developed by the author (Moser 1976, Moser 1978), a monolingual introductory course to simultaneous interpretation was developed which served as a guideline for selecting students for interpretation in the Graduate Division of Translation and Conference Interpretation at the Monterey Institute of International Studies. Data with regard to student performance in this course were collected over a 4-year period and the type of recommendation issued was compared to the examination results of these students at the end of their first and second (last) year of studies. A significant relationship was found to exist between type of recommendation issued and examination results.

\section{THE COURSE}

The theoretical underpinnings and the rational for the exercises listed below can be found in Moser (1978). The course was offered in English (no foreign language was used except in the dual-task training) and was programmed for 10 weeks. The following four types of exercises were used.

1. Shadowing: The central assumption underlying both the dual-task training and the shadowing exercises is that the difficulty of carrying out either the additional task or the shadowing will absorb much of the student's attention, while at the same time he is forced to listen.

2. Dual-task training, memory exercises : The primary task was always listening to a recorded speech. The second task was designed to distract the student's attention from the primary task, in analogy to the simultaneity of listening and speaking in simultaneous interpreting, through the student's counting out loud in English or in his Blanguage, either forward or backward. Student's attention to the primary task was checked by way of an oral recall test of the passages' main ideas.

3. Paraphrasing : Students' ability to render the meaning of a message in other words and in different syntactic constructions was developed. Students paraphrased recorded speeches at normal tape speed.

4. Processing of numbers : From a language information processing point of view, the processing of numbers differs from that of continuous text in that numbers are largely unpredictable, i.e. one has to devote full attention to the incoming message, whereas, as discussed in another place (Moser 1978), continuous text allows and even requires hypothesizing on the input. Thus, when numbers appear in a continuous text, the interpreter has to switch his processing procedures. Students were required to shadow the original recording (texts containing a great many numbers) and write down all numbers. Papers were collected, corrected and matched with the student's shadowing performance to gain sufficient insight in the student's overall performance in this task. 


\section{CRITERIA FOR RECOMMENDATIONS AND EVALUATION OF PERFORMANCE}

Three types of recommendations were issued at the end of the 10-week course : 1) Recommendation for interpreting ;

2) Qualified recommendation for interpreting ;

3) No recommendation for interpreting.

The main criterion for these recommendations was the progress students made during the 10-week course towards a level that was considered adequate for beginning simultaneous interpretation courses. Students who were recommended reached the stipulated level in various ways, either progressing slowly towards the desired level or putting it all together only at the end of the course. Students receiving qualified recommendations either did not reach that level at all or reached the level but were poor performers in other aspects (see additional criteria listed below). A student was not recommended if he did not reach the required level and performed poorly in most or all of the other aspects. The following additional criteria entered into the final judgment : Command of the English language, pronunciation and enunciation, ability to cope with stress, assertiveness, resilience, microphone technique.

Of the additional criteria, superior command of the English language was the most important. Any weakness in this aspect invariably showed up in the paraphrasing exercises, where it manifested itself in a lack of progress. Although in certain cases, a weakness in this area resulted in a qualified recommendation, experience has proven that our 2-year program is so demanding in many other respects that not much time can be devoted to remedying weaknesses in the student's native language.

Pronunciation and enunciation were next in importance; pronunciation was more often a problem for non-native speakers of English, whereas enunciation was quite frequent with English native speakers. If no progress was discernible over the 10-week period, students were given a qualified recommendation, as poor enunciation coupled with sometimes not so perfect interpretation equipment is most likely going to result in a simultaneous interpretation that is unintelligible for the delegate.

Ability to cope with stress was tested by using the exercises as testing tools. Increased input rates, dual-task training, text material with low redundancy all produce stress, mostly time stress. While occasional incidences of fatigue were considered normal, regular failure to cope with increases in difficulty was taken as a sign of the student's inability to cope with stressful situations. The test session at the end of the course was not so much designed for observation of students' performance in any given exercise, as it was meant to reveal students' ability to perform in these exercises under added stress. In a number of cases, students themselves admitted that they were not able to cope with the stress and they decided not to pursue simultaneous interpretation.

Assertiveness was another criterion used to evaluate students. In this respect the students' personal problems usually entered into the picture. Insecure students had more difficulty making progress than had students who revealed normal to high degrees of self-confidence. The former were usually able to improve only if they simultaneously concentrated on increasing their self-confidence generally. An interpreter who is not assertive is usually unable to convince his audience. Lack of progress in this respect was considered a hurdle on the road to successful professional practice. Unwillingness to work on one's own personal problems, even if adequate progress was shown in all other areas, still resulted in a qualified recommendation.

Resilience was tested over the course of any individual class period. Signs of fatigue after 10 minutes spent in a 60-minute class, without any improvement towards the end of the course, were considered serious handicaps. Resilience requires a certain build-up through practice and is a vital prerequisite for sustaining the high performance 
level in simultaneous interpretation over the course of at least six hours, the normal working time in the profession.

Lastly, microphone technique entered into the final judgment. Here, considerably more leeway was granted with regard to improvement, as continuous practice in the booth is most likely to result in improved microphone presence.

\section{THE STUDY}

The hypothesis underlying the study was that students who receive a recommendation are more likely to pass the qualifying examinations at the end of their first year of study and the final professional examinations at the end of their second year of study than those students who receive only a qualified or no recommendation at all. Data were collected for 114 students registered for the introductory course in simultaneous interpretation over a 4-year period (1978-1981). 58 students were recommended for interpretation, 28 received a qualified recommendation and 28 were not recommended. After adjusting the data for students who left the program before taking their qualifying exams, the respective numbers used in the statistical analyses were as follows :

$\begin{array}{ll}\text { Recommendation } & 50 \\ \text { Qualified recommendation } & 16 \\ \text { No recommendation } & \underline{17} \\ & 83\end{array}$

\section{Examination results for qualifying exams :}

Recommendation

Qualified recommendation

No recommendation

Totals

\begin{tabular}{rrr} 
Pass & $1+2$ & Fail \\
36 & 50 & 14 \\
8 & 16 & 8 \\
5 & 17 & 12 \\
\hline 49 & 83 & 34
\end{tabular}
Chi-square : 10,195
df $: 2$
$\mathrm{p}: 0,0061$
$\alpha: 0,01$

After adjusting the data for students who left the program before their final exams, the respective numbers used in the statistical analyses for final exams were as follows :

Recommandation

Qualified recommendation

No recommendation

40

$\frac{8}{57}$

\section{Examination results for final exams :}

Recommendation

Qualified recommendation

No recommendation

Totals

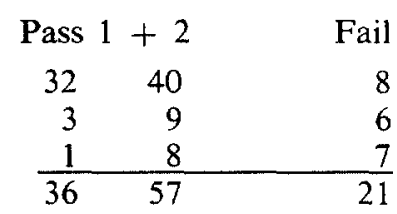

Chi-square : $17,116 \quad$ df : $2 \quad p: 0,000192 \quad \alpha: 0,001$ 


\section{CONCLUSION}

The highly significant results of the study underline the necessity for a comprehensive analysis of a complex skill such as simultaneous interpreting and point to the desirability of observing a student over an extended period of time before issuing a judgment on interpreting potential. Such an extended period of observation not only gives the student a chance to develop according to his own learning abilities, but also allows the teacher/professional to judge the student's potential with greater accuracy.

\section{BIBLIOGRAPHY}

GERVER, D., S. LAMBERT, P. LONGLEY \& J. LONG (1981) : Testing Trainee Interpreters. A Pilot Study, unpubl. manuscript.

KEISER, Walter (1978) : "Selection and Training of Conference Interpreters", in D. Gerver and H.W. Sinaiko (eds.), Language, Interpretation and Communication, New York/London, Plenum Press.

LONGLEY, Patricia (1978) : "An Integrated Programme for Training Interpreters", in D. Gerver and H.W. Sinaiko (eds.), Language, Interpretation and Communication, New York/London, Plenum Press.

MILLER, George A. (1956) : "The Magical Number 7 Plus or Minus Two : Some Limits on our Capacity for Processing Information", in Psychological Review 63, pp. 81-97.

MOSER, Barbara (1976) : Simultaneous Translation : Linguistic, Psycholinguistic and Human Information Processing Aspects, University of Innsbruck, unpubl. Ph.D. dissertation.

MOSER, Barbara (1978) : "Simultaneous Interpretation : A Hypothetical Model and its Practical Application", in D. Gerver and H.W. Sinaiko (eds.), Language, Interpretation and Communication, New York/London, Plenum Press.

NAMY, Claude (1978) : "Reflexion on the Training of Simultaneous Interpreters : A Metalinguistic Approach", in D. Gerver and H.W. Sinaiko (eds.), Language, Interpretation and Communication, New York/London, Plenum Press. 